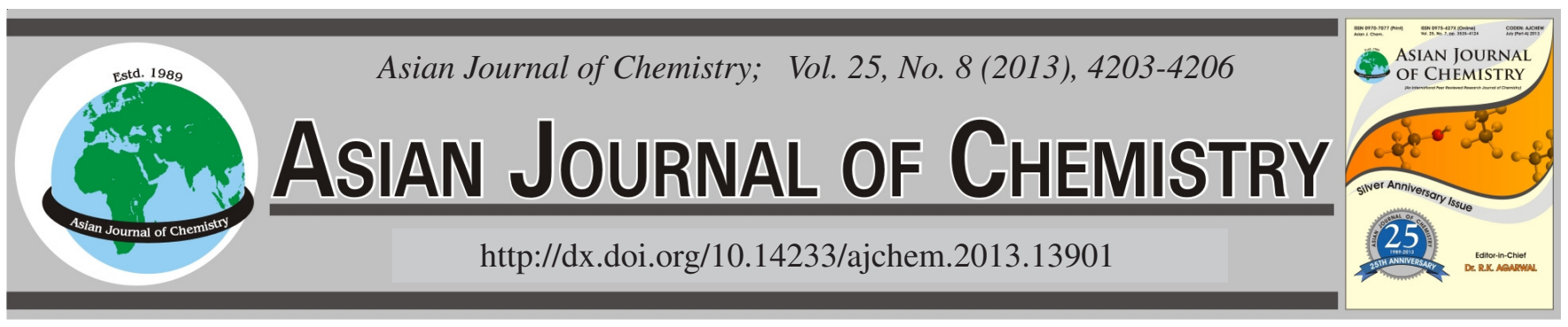

\title{
Synthesis, Characterization and Preliminary in vitro Antibacterial Screening Activity of Metal Complexes Derivatives of 2-\{[5-(4-Nitrophenyl)-1,3,4-thiadiazol-2-ylimino]methyl $\}$ phenol
}

\author{
Yip-Foo Win ${ }^{1, *}$, Emad Yousif ${ }^{2, *}$, Sie-Tiong HA $^{1}$ and Ahmed MaJeED ${ }^{2}$ \\ ${ }^{1}$ Department of Chemical Science, Faculty of Science, Universiti Tunku Abdul Rahman, Perak Campus, Jalan Universiti, Bandar Barat, 31900 \\ Kampar, Perak, Malaysia \\ ${ }^{2}$ Department of Chemistry, College of Science, Al-Nahrain University, Baghdad, Iraq \\ *Corresponding author: Fax: +605 4661676; Tel: +605 4688888; E-mail: williamyfw@yahoo.com
}

(Received: 13 April 2012;

Accepted: 4 February 2013)

AJC-12927

\begin{abstract}
A total of five new metal complexes derivatives of 2-\{[5-(4-nitrophenyl)-1,3,4-thiadiazol-2-ylimino]methyl $\}$ phenol (HL) with the metal ions $[\mathrm{Ni}(\mathrm{II}), \mathrm{Cu}(\mathrm{II}), \mathrm{Zn}(\mathrm{II}), \mathrm{Cd}(\mathrm{II})$ and $\mathrm{Sn}(\mathrm{II})]$ have been successfully prepared in alcoholic medium. The complexes obtained are characterized quantitatively and qualitatively by using microelemental analysis, FTIR spectroscopy, UV-visible spectroscopy, mass spectroscopy, ${ }^{1} \mathrm{H}$ and ${ }^{13} \mathrm{C}$ NMR, magnetic susceptibility and conductivity measurements. From the spectral study, all the complexes obtained as monomeric structure and the metals centre moieties are four-coordinated with distorted tetrahedral geometry except $\mathrm{Cu}$ (II) complex which existed as a distorted square planar geometry. The preliminary in vitro antibacterial screening activity revealed that complexes 1-5 showed moderate activity against tested bacterial strains and slightly higher compared to the parent ligand.
\end{abstract}

Key Words: 1,3,4-Thiadiazole derivatives, Metal complexes, In vitro antibacterial activity.

ᄂ - - - - - - - - - - - - - - - - - - - - - - - - -

\section{INTRODUCTION}

The synthesized and structural study of 1,3,4-thiadiazoles derivatives are a class of heterocyclic compound which has attracted significant interest in medicinal chemistry and have a wide range of pharmaceutical and biological activities including antimicrobial, antifungal, antiinflammatory and antihypertensive ${ }^{1-7}$. Up-to-date, numerous studies have been carried out to synthesis various type of new 1,3,4-thiadiazoles derivatives by extending the thiadiazoles ring with some active organic compounds to form new Schiff bases compounds ${ }^{1-8}$. In addition, the chemistry and the applications of these new Schiff bases thiadiazoles derivatives could be extensively study by coordinating to various metal ion moieties. As a result, the structural-activity relationship study of 1,3,4-thiadiazoles could be expanded in the near future.

As the continuation interest of our study of transition metal complexes $^{9-14}$, here we present the synthesis and characterization of new complexes derivatives of 2-\{[5-(4-nitrophenyl)-1,3,4thiadiazol-2-ylimino]methyl $\}$ phenol. Moreover, the preliminary in vitro antibacterial screening activities of the complexes obtained are carried out and the results are reported herein.

\section{EXPERIMENTAL}

All the reagents, starting materials as well as solvents were purchased commercially and used without any further purifi- cation. The melting points were recorded on a hot stage Gallen Kamp melting point apparatus. Elemental C, H, N and S analysis were carried out on a Fison EA 1108 analyzer. The Infrared (FTIR) spectra were recorded by using FTIR.8300 Shimadzu spectrophotometer by using CsI disc in the frequency range of 4000-200 $\mathrm{cm}^{-1}$. The ultraviolet-visible (UVVIS) spectra were recorded by using Shimadzu UV-VIS. 160 A-Ultra-violet spectrophotometer in the range of 200-1100 $\mathrm{nm}$. The magnetic susceptibility values were obtained at room temperature using Magnetic Susceptibility Balance Bruke Magnet B.M.6. Conductivity measurements were carried out by using WTW conductivity meter, atomic absorption measurements were obtained by using Shimadzu 680cc-flame. The spectra of ${ }^{1} \mathrm{H}$ and ${ }^{13} \mathrm{C}$ NMR spectra were recorded on a Jeol $400 \mathrm{MHz}$ spectrometer using deuterated DMSO- $d_{6}$ as the solvent and tetramethylsilane, TMS as the internal standard. Mass spectra were recorded on a Micromass UK PLATFORM II LC-MS spectrometer.

Preparation of 2-\{[5-(4-nitrophenyl)-1,3,4-thiadiazol2-ylimino]methyl\}phenol, HL: A mixture of 4-nitrobenzoic acid $(0.01 \mathrm{~mol})$, thiosemicarbazide $(0.01 \mathrm{~mol})$ and phosphorus oxychloride $(5 \mathrm{~mL})$ was heating under reflux for $3 \mathrm{~h}$. Upon cooling, distilled water $(50 \mathrm{~mL})$ was added to the mixture and the heating under reflux was carried out for another $4 \mathrm{~h}$. The obtained filtrate was neutralized with potassium hydroxide. 
Then, the precipitate was filtered and washed with cold distilled water and finally recrystallized by using ethanol-water solvent mixture to obtain 5-(4-nitrophenyl)-1,3,4-thiadiazol-2-amine. In the next reaction, 5-(4-nitrophenyl)-1,3,4-thiadiazol-2amine $(0.01 \mathrm{~mol})$ and salicyladehyde $(0.01 \mathrm{~mol})$ was heating under reflux for $3 \mathrm{~h}$ to obtained the yellow precipitate. The precipitated obtained was filtered and crystallized from ethanol to give the respective 2-\{[5-(4-nitrophenyl)-1,3,4-thiadiazol2-ylimino]methyl $\}$ phenol, HL ligand for the further complexation with metal ion. The stepwise preparation of the ligand (HL) is shown in Fig. 1.

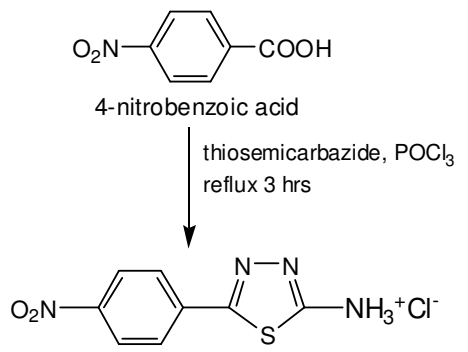

5-(4-nitrophenyl)-1,3,4-thiadiazol-2-aminium chloride

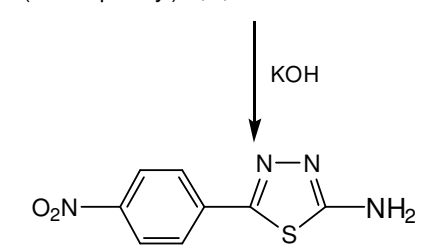

5-(4-nitrophenyl)-1,3,4-thiadiazol-2-amine

salicyladehyde reflux $3 \mathrm{hrs}$

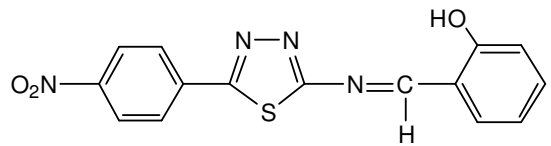

2-\{[5-(4-nitrophenyl)-1,3,4-thiadiazol-2-ylimino]methyl $\}$ phenol

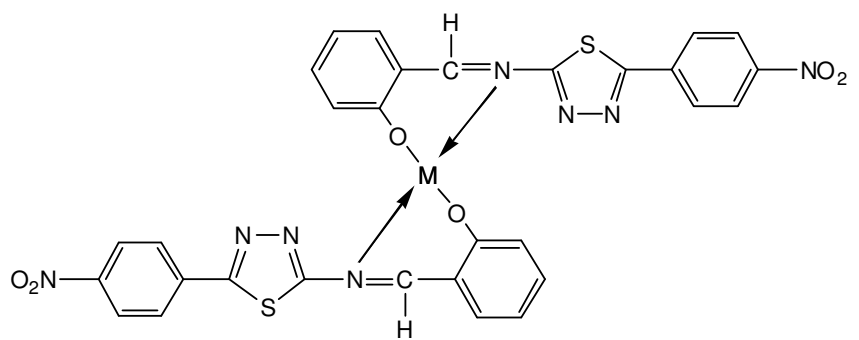

Fig. 1. Structure of acid (HL) and the proposed structure of complexes 1-5 $(\mathrm{M}=\mathrm{Ni}, \mathrm{Cu}, \mathrm{Zn}, \mathrm{Cd}$ or $\mathrm{Sn})$
Preparation of complexes: An ethanolic solution of the corresponding metal(II) compounds [nickel(II) chloride hexahydrate, tin(II) chloride, copper(II) chloride dihydrate, cadmium(II) chloride dihydrate and zinc(II) chloride] was added to ethanolic solution of 2-\{[5-(4-nitrophenyl)-1,3,4thiadiazol-2-ylimino] methyl \}phenol (HL) in 1:2 (metal: ligand) molar ratio. Then, the mixture was heating under reflux for $0.5 \mathrm{~h}$ and coloured precipitates were obtained. Later, the precipitates were filtered out, washed with distilled water and finally recrystallized from ethanol.

\section{RESULTS AND DISCUSSION}

In general, the complexes obtained by heating under reflux of respective metal salts with ligand (HL) in 1:2 molar ratio. The purity of the ligand (HL) and its metal complexes 1-5 obtained were checked by TLC using silica gel-G as adsorbent. Complexes 1-5 gave a sharp melting point indicated the isolation of fairly pure complexes. The micro-elemental analysis for $\mathrm{C}, \mathrm{H}, \mathrm{N}$ and $\mathrm{S}$ as well as the molecular weight of the complexes obtained were in agreement with the predicted formula for complexes 1-5. An outline of the proposed structure for complexes 1-5 and ligand (HL) are depicted in Fig. 1. The melting point, micro-elemental analysis and $\mathrm{m} / \mathrm{z}$ data are given in Table-1.

The infrared spectrum of ligand (HL) showed some characteristic stretching bands at 1635 and $1116 \mathrm{~cm}^{-1}$ assigned to $v(\mathrm{C}=\mathrm{N})$ and $\mathrm{v}(\mathrm{C}-\mathrm{O})$, respectively which could be found in complexes 1-5. The exceptional case is that the $v(C=N)$ of complexes 1-5 were found to be shifted to a lower wavelength number compared to the ligand, HL signifying that the coordination took place via the nitrogen atom of the ligand (HL) ${ }^{15}$. In addition, the stretching of metal-oxygen and metal-nitrogen bands of the complexes appeared in the lower wavelength region in the range of 556-500 and 488-432 $\mathrm{cm}^{-1}$ also signifies the complexation through nitrogen and oxygen atoms from the ligand ${ }^{16}$. The important infrared data of the ligand, HL and complexes 1-5 are given in Table-2.

The ultraviolet visible electronic spectrum of the ligand, HL and complexes 1-5 in ethanol solution are given in Table-3. The acid showed three bands at 210,254 and $346 \mathrm{~nm}$ attributed to $\pi \rightarrow \pi^{*}, \pi \rightarrow \pi^{*}$ and $\mathrm{n} \rightarrow \pi^{*}$ electronic transition, respectively. From Table-3, complexes 1, $\mathbf{4}$ and $\mathbf{5}$ also showed the similar electronic transition as observed in the ligand, HL. For complexes $\mathbf{2}$ and $\mathbf{3}$, the electronic transitions of the metal $d$ orbitals ( $d$ - $d$ electronic transition) observed in the $\mathrm{Ni}$ (II) and $\mathrm{Cu}(\mathrm{II})$ located in the visible region as an extra information. In $\mathrm{Ni}(\mathrm{II}), d-d$ electronic transition appeared at 728 and 1322

\begin{tabular}{|c|c|c|c|c|c|c|c|c|}
\hline \multirow{3}{*}{ Compounds } & \multirow{3}{*}{$\begin{array}{c}\text { MELTING PC } \\
\text { Physical } \\
\text { appearance }\end{array}$} & \multirow{3}{*}{ m.p. $\left({ }^{\circ} \mathrm{C}\right)$} & \multicolumn{2}{|r|}{$\begin{array}{l}\text { TABLE-1 } \\
\text { L DATA }(\%)\end{array}$} & $\mathrm{ND}$ m/z VALUE & F HL AND C & MPLEXES 1-5 & \multirow{3}{*}{$\mathrm{m} / \mathrm{z}$} \\
\hline & & & \multicolumn{5}{|c|}{ Elemental (\%) } & \\
\hline & & & $\mathrm{C}$ & $\mathrm{H}$ & $\mathrm{N}$ & $\mathrm{S}$ & $\mathrm{M}$ & \\
\hline HL & Yellow & 113-115 & $55.44(55.04)$ & $3.33(3.36)$ & $17.32(17.12)$ & 9.99 (9.78) & - & 327.0 \\
\hline $\mathrm{Ni}(\mathrm{L})_{2}, \mathbf{1}$ & Blue & $140-142$ & $25.25(25.33)$ & $1.34(1.55)$ & $7.55(7.88)$ & $4.44(4.50)$ & $8.45(8.26)$ & 710.7 \\
\hline $\mathrm{Cu}(\mathrm{L})_{2}, 2$ & Green & $160-162$ & $25.33(25.15)$ & $1.22(1.54)$ & $7.90(7.82)$ & $4.34(4.47)$ & $9.02(8.88)$ & 715.5 \\
\hline $\mathrm{Zn}(\mathrm{L})_{2}, \mathbf{3}$ & Yellow & $129-131$ & $24.89(25.09)$ & $1.33(1.53)$ & $7.55(7.81)$ & $4.33(4.46)$ & $8.98(9.11)$ & 717.4 \\
\hline $\mathrm{Cd}(\mathrm{L})_{2}, 4$ & Yellow & $111-114$ & $23.12(23.55)$ & $1.32(1.44)$ & $7.55(7.32)$ & $4.33(4.18)$ & $14.44(14.70)$ & 764.4 \\
\hline $\mathrm{Sn}(\mathrm{L})_{2}, \mathbf{5}$ & Yellow & $135-137$ & $23.02(23.35)$ & $1.09(1.42)$ & $7.55(7.26)$ & $4.20(4.15)$ & $15.56(15.40)$ & 770.69 \\
\hline
\end{tabular}

Calculated value are given in parentheses. 


\begin{tabular}{lcccc}
\hline \multicolumn{5}{c}{ TABLE-2 } \\
\multicolumn{5}{c}{ KEY INFRARED DATA OF HL AND COMPLEXES 1-5 } \\
\hline \multirow{2}{*}{ Compounds } & \multicolumn{4}{c}{ Wavelength $\left(\mathrm{cm}^{-1}\right)$} \\
\cline { 2 - 5 } & $v(\mathrm{C}=\mathrm{N})$ & $v(\mathrm{C}-\mathrm{O})$ & $v(\mathrm{M}-\mathrm{O})$ & $v(\mathrm{M}-\mathrm{N})$ \\
\hline $\mathrm{HL}$ & 1635 & 1116 & - & - \\
$\mathrm{Ni}(\mathrm{L})_{2}, \mathbf{1}$ & 1602 & 1122 & 510 & 488 \\
$\mathrm{Cu}(\mathrm{L})_{2}, \mathbf{2}$ & 1600 & 1120 & 504 & 482 \\
$\mathrm{Zn}(\mathrm{L})_{2}, \mathbf{3}$ & 1610 & 1109 & 500 & 432 \\
$\mathrm{Cd}(\mathrm{L})_{2}, \mathbf{4}$ & 1608 & 1110 & 510 & 444 \\
$\mathrm{Sn}(\mathrm{L})_{2}, \mathbf{5}$ & 1608 & 1121 & 556 & 480 \\
\hline
\end{tabular}

\begin{tabular}{lcc} 
& \multicolumn{2}{c}{ TABLE-3 } \\
& \multicolumn{2}{c}{$\begin{array}{c}\text { ELECTRONIC SPECTRA DATA OF HL } \\
\text { AND COMPLEXES 1-5 IN ETHANOL }\end{array}$} \\
\hline \multicolumn{1}{c}{ Comp. } & $\begin{array}{c}\text { Absorption bands } \\
(\mathrm{nm})\end{array}$ & Assigned transition \\
\hline $\mathrm{HL}$ & $210,254,346$ & $\pi \rightarrow \pi^{*}, \pi \rightarrow \pi^{*}, \mathrm{n} \rightarrow \pi^{*}$ \\
$\mathrm{Ni}(\mathrm{L})_{2}, \mathbf{1}$ & 245,349728 & $\pi \rightarrow \pi^{*}, \mathrm{n} \rightarrow \pi^{*}$, \\
& $($ av. $), 1322$ (calc.) & ${ }^{3} \mathrm{~T}_{1}(\mathrm{~F}) \rightarrow{ }^{3} \mathrm{~T}_{1}(\mathrm{P}),{ }^{3} \mathrm{~T}_{1}(\mathrm{~F}) \rightarrow{ }^{3} \mathrm{~A}_{2}(\mathrm{~F})$ \\
$\mathrm{Cu}(\mathrm{L})_{2}, \mathbf{2}$ & $245,348,440$ & $\pi \rightarrow \pi^{*}, \mathrm{n} \rightarrow \pi^{*}, \mathrm{~L} \rightarrow \mathrm{Cu}(\mathrm{C} . \mathrm{T})$, \\
& $500,680,904$ & ${ }^{2} \mathrm{~B}_{1 \mathrm{~g}} \rightarrow{ }^{1} \mathrm{~A}_{1 \mathrm{~g}},{ }^{2} \mathrm{~B}_{1 \mathrm{~g}} \rightarrow{ }^{2} \mathrm{~B}_{2 \mathrm{~g}},{ }^{2} \mathrm{~B}_{1 \mathrm{~g}} \rightarrow \mathrm{E}_{\mathrm{g}}$ \\
$\mathrm{Zn}(\mathrm{L})_{2}, \mathbf{3}$ & 252,349 & $\pi \rightarrow \pi^{*}, \mathrm{n} \rightarrow \pi^{*}$ \\
$\mathrm{Cd}(\mathrm{L})_{2}, \mathbf{4}$ & 250,350 & $\pi \rightarrow \pi^{*}, \mathrm{n} \rightarrow \pi^{*}$ \\
$\mathrm{Sn}(\mathrm{L})_{2}, \mathbf{5}$ & 238,323 & $\pi \rightarrow \pi^{*}, \mathrm{n} \rightarrow \pi^{*}$ \\
\hline
\end{tabular}

calculated) nm assigned to the ${ }^{3} \mathrm{~T}_{1}(\mathrm{~F}) \rightarrow{ }^{3} \mathrm{~T}_{1}(\mathrm{P})$ and ${ }^{3} \mathrm{~T}_{1}(\mathrm{~F}) \rightarrow$ ${ }^{3} \mathrm{~A}_{2}(\mathrm{~F})$ transition, respectively ${ }^{17}$. For $\mathrm{Cu}(\mathrm{II})$, the bands appeared at $440,550,680$ and $904 \mathrm{~nm}$ were attributed to the $\mathrm{L}$ (ligand) $\rightarrow \mathrm{Cu}$ (charge transfer, C.T.), ${ }^{2} \mathrm{~B}_{1 \mathrm{~g}} \rightarrow{ }^{1} \mathrm{~A}_{1 \mathrm{~g}},{ }^{2} \mathrm{~B}_{1 \mathrm{~g}} \rightarrow{ }^{2} \mathrm{~B}_{2 \mathrm{~g}}$ and ${ }^{2} \mathrm{~B}_{1 \mathrm{~g}}$ $\rightarrow \mathrm{E}_{\mathrm{g}}$, respectively ${ }^{18,19}$.

The ${ }^{1} \mathrm{H}$ NMR spectra of complexes 1-5 gave an additional support for the formation of the complexation. In the ${ }^{1} \mathrm{H}$ NMR spectra of ligand, HL showed a sharp peaks, $\delta(\mathrm{OH})$ at 9.90 ppm which was absent in the spectra of the complexes 1-5 indicated deprotonation and complexation of ligand anion to metal ions. The ${ }^{1} \mathrm{H}$ NMR spectra of complexes 1-5 exhibited some similarities to the ligand, HL with the occurrence of $-\mathrm{N}=\mathrm{C} \underline{\mathrm{H}}-$ and aromatic protons signals centering at $\delta \approx 7.35$ $\mathrm{ppm}$ and in the range of 8.23-9.20 ppm, respectively ${ }^{20}$. From the ${ }^{13} \mathrm{C}$ NMR study, all the complexes obtained also exhibited some similarities to the ligand, HL with the occurrence of $-\mathrm{N}=\underline{\mathrm{CH}}-$ carbon signals centering at $\delta \approx 111.00 \mathrm{ppm}$ and thiadiazole carbons signals centering at $\delta \approx 87.60$ and 90.78 $\mathrm{ppm}$, respectively. Moreover, the aromatic carbons signals of both complexes 1-5 and ligand, HL were located at the downfield region in the range of 125.42-132.61 ppm. Generally, there is no uncharacterized peak in the ${ }^{1} \mathrm{H}$ and ${ }^{13} \mathrm{C}$ NMR spectra of ligand, HL and complexes 1-5 signify the purity of the samples obtained. The ${ }^{1} \mathrm{H}$ and ${ }^{13} \mathrm{C}$ NMR spectra data of ligand, HL and complexes 1-5 are given in Table-4.

Magnetic moment measurements are widely used in studying transition metal complexes and the magnetic moment of complexes 1-5 are given in Table-5. The magnetic properties are due to the presence of unpaired electrons in the partially filled $d$-orbital in the outer shell of these elements. These magnetic measurements give an outline about the electronic state of the metal ion in the complexes. The magnetic moment value of complex 1 was $c a .4 .33$ B.M. and referred as paramagnetic and the geometry of nickel(II) metal centre was distorted tetrahedral. Complex 2 showed that the magnetic moment value at 0.85 B.M. and believed that the copper(II) metal moiety exhibited distorted square planar geometry ${ }^{21}$. Complexes 3-5 are diamagnetic and there were no magnetic moment recorded in this study. Based on the molar conductivity measurements study of complexes 1-5 in (Table-5), all the prepared complexes were found to be non-electrolyte.

\begin{tabular}{lccc}
\multicolumn{5}{c}{ TABLE-5 } \\
CONDUCTIVITY MEASUREMENTS AND MAGNETIC \\
\multicolumn{4}{c}{ MOMENT OF HL AND METAL COMPLEXES 1-5 IN DMF } \\
\hline Compounds & $\begin{array}{c}\text { Conductivity } \\
(\mu \mathrm{S} / \mathrm{cm})\end{array}$ & $\begin{array}{c}\text { Magnetic } \\
\text { moment }(\mathrm{BM})\end{array}$ & $\begin{array}{c}\text { Proposed } \\
\text { structure }\end{array}$ \\
\hline $\mathrm{HL}$ & - & - & - \\
$\mathrm{Ni}(\mathrm{L})_{2}, \mathbf{1}$ & 20 & 4.33 & Tetrahedral \\
$\mathrm{Cu}(\mathrm{L})_{2}, \mathbf{2}$ & 17 & 0.85 & Square planar \\
$\mathrm{Zn}(\mathrm{L})_{2}, \mathbf{3}$ & 17 & 0.00 & Tetrahedral \\
$\mathrm{Cd}(\mathrm{L})_{2}, \mathbf{4}$ & 9 & 0.00 & Tetrahedral \\
$\mathrm{Sn}(\mathrm{L})_{2}, \mathbf{5}$ & 20 & 0.00 & Tetrahedral \\
\hline
\end{tabular}

All the complexes obtained were studied in ethanol solution to determine the $[\mathrm{M} / \mathrm{L}]$ ratio in the complex by Job's Method $^{22}$. A series of solutions were prepared with a constant concentration $\left(10^{-3} \mathrm{M}\right)$ of the metal ion and ligand, HL. The $[\mathrm{M} / \mathrm{L}]$ ratio was determined from the relationship between the absorption of the absorbed light and the mole ratio of $[\mathrm{M} / \mathrm{L}]$. The study showed that the metal to ligand, HL ratio was [1/2] for complexes 1-5 and found to be similar to the solid state. Based on the spectral study, complexes 1-5 exhibited distorted tetrahedral geometry except complex $\mathbf{2}$ (distorted square planar). The proposed structures of complexes $\mathbf{1 - 5}$ are depicted in Fig. 1.

The preliminary in vitro antibacterial screening activity of ligand (HL) and complexes 1-5 are given in Table-6. The synthesized complexes and ligand, HL were screened for their in vitro antibacterial activity against Staphylococcus aureus,

\begin{tabular}{|c|c|c|c|c|c|c|}
\hline \multicolumn{7}{|c|}{$\begin{array}{c}\text { TABLE-4 } \\
{ }^{1} \mathrm{H} \text { AND }{ }^{13} \mathrm{C} \text { NMR DATA OF HL AND METAL COMPLEXES 1-5 IN DMSO- } d_{6}\end{array}$} \\
\hline \multicolumn{7}{|c|}{ Chemical shift, $\delta(\mathrm{ppm})$} \\
\hline \multicolumn{4}{|c|}{${ }^{1} \mathrm{H}$ NMR } & \multicolumn{3}{|c|}{${ }^{13} \mathrm{C}$ NMR } \\
\hline Compounds & $-\mathrm{N}=\mathrm{C} \underline{\mathrm{H}}-$ & Aromatic & $\mathrm{OH}$ & $-\mathrm{N}=\underline{\mathrm{CH}}-$ & Thiadiazole & Aromatic \\
\hline $\mathrm{HL}$ & $7.38(\mathrm{~s})$ & $8.23-9.05(\mathrm{~m})$ & 9.90 & 111.12 & $87.70,90.79$ & $125.43-132.54$ \\
\hline $\mathrm{Ni}(\mathrm{L})_{2}, \mathbf{1}$ & $7.32(\mathrm{~s})$ & $8.33-9.16(\mathrm{~m})$ & - & 112.67 & $87.66,90.77$ & $125.57-132.51$ \\
\hline $\mathrm{Cu}(\mathrm{L})_{2}, 2$ & $7.31(\mathrm{~s})$ & $8.29-9.17(\mathrm{~m})$ & - & 110.85 & $87.66,90.80$ & $125.52-132.61$ \\
\hline $\mathrm{Zn}(\mathrm{L})_{2}, 3$ & $7.33(\mathrm{~s})$ & $8.39-9.20(\mathrm{~m})$ & - & 111.49 & $87.64,90.79$ & $125.42-132.52$ \\
\hline $\mathrm{Cd}(\mathrm{L})_{2}, 4$ & $7.32(\mathrm{~s})$ & $8.27-9.19(\mathrm{~m})$ & - & 112.34 & $87.61,90.76$ & $125.52-132.61$ \\
\hline $\mathrm{Sn}(\mathrm{L})_{2}, \mathbf{5}$ & $7.35(\mathrm{~s})$ & $8.31-9.17(\mathrm{~m})$ & - & 110.56 & $87.66,90.78$ & $125.42-132.54$ \\
\hline
\end{tabular}




\begin{tabular}{|c|c|c|c|c|c|c|}
\hline \multirow{4}{*}{ Comp. } & \multicolumn{6}{|c|}{$\begin{array}{c}\text { TABLE-6 } \\
\text { ELIMINARY IN VITRO ANTIBACTERIAL SCREENING ACTIVITY OF HL AND COMPLEXES 1-5 }\end{array}$} \\
\hline & \multicolumn{6}{|c|}{ Inhibition zone $(\mathrm{mm})$} \\
\hline & \multicolumn{2}{|c|}{ Staphylococcus aureus } & \multicolumn{2}{|c|}{ Salmonella typhi } & \multicolumn{2}{|c|}{ Escherichia coli } \\
\hline & $100(\mu \mathrm{g} / \mathrm{mL})$ & $200(\mu \mathrm{g} / \mathrm{mL})$ & $100(\mu \mathrm{g} / \mathrm{mL})$ & $200(\mu \mathrm{g} / \mathrm{mL})$ & $100(\mu \mathrm{g} / \mathrm{mL})$ & $200(\mu \mathrm{g} / \mathrm{mL})$ \\
\hline $\mathrm{HL}$ & - & + & + & + & + & + \\
\hline $\mathrm{Ni}(\mathrm{L})_{2}, 1$ & + & + & + & ++ & + & + \\
\hline $\mathrm{Cu}(\mathrm{L})_{2}, \mathbf{2}$ & ++ & ++ & + & + & ++ & ++ \\
\hline $\mathrm{Zn}(\mathrm{L})_{2}, \mathbf{3}$ & - & + & + & ++ & ++ & ++ \\
\hline $\mathrm{Cd}(\mathrm{L})_{2}, \mathbf{4}$ & ++ & + & ++ & + & ++ & +++ \\
\hline $\operatorname{Sn}(\mathrm{L})_{2}, \mathbf{5}$ & ++ & + & ++ & ++ & ++ & ++ \\
\hline
\end{tabular}

Salmonella typhi and Escherishia coli bacterial strains by inhibition zone method using agar diffusion method ${ }^{23,24}$. In this method a standard $6.35 \mathrm{~mm}$ diameter sterilized filter paper disc impregnated with the compound (200 and $100 \mu \mathrm{g} / \mathrm{mL}$ in DMSO) was placed on an agar plate seeded with the test bacterial strains. The plates were incubated for $24 \mathrm{~h}$ at $37^{\circ} \mathrm{C}$. The activity was determined by measuring the diameter of the inhibition zone (in $\mathrm{mm}$ ) and streptomycin was used as the standard control. The preliminary screening results revealed that complexes $\mathbf{1 - 5}$ showed a significant activity compared to the ligand, HL. Overall, the activities of all the complexes obtained were found to be moderate even though higher concentration were applied. This may be due to the bulkiness of the molecule with a complicated structure which in turn restrict their mobility to the target cell or active site although all the complexes obtained as a monomeric and four-coordinated metal(II) moiety.

\section{Conclusion}

The ligand 2-\{[5-(4-nitrophenyl)-1,3,4-thiadiazol-2ylimino]methyl $\}$ phenol, HL was successfully synthesized. The ligand, HL was coordinated to five different metal ions via oxygen and nitrogen atoms to afford the corresponding complexes. All the complexes were four-coordinated and exhibited distorted tetrahedral geometry except complex 2 (distorted square planar). Preliminary in vitro antibacterial study indicated that all the complexes obtained showed moderate activity against the tested bacterial strains and slightly higher activity compared to the ligand, HL.

\section{ACKNOWLEDGEMENTS}

The authors thank University of Al-Nahrain and Universiti Tunku Abdul Rahman for the UTAR Research Fund (Project No. IPSR/RMC/UTARRF/C1-11/C07) and for financial support and technical assistance on this work.

\section{REFERENCES}

1. E.A. Elzahany, K.H. Hegab, S.K.H. Khalil and N.S. Youssef, Aust. J. Basic Appl. Sci., 2, 210 (2008).

2. K.M. Gaber, H. Mabrouk and S.S. Al-Shihrt, Egypt. J. Chem., 44, 191 (2001).

3. F. Hadizadeh and R. Vosoogh, J. Heterocycl. Chem., 45, 1 (2008).

4. S.M. Lu and R.Y. Chen, Org. Preparations Proced. Int., 32, 302 (2000).

5. A. Jarrahpour, D. Khalili, E.D. Clercq, C. Salmi and J. Michel, Molecules, 12, 1720 (2007).

6. N.H. Al-Sha'alan, Molecules, 12, 1080 (2007)

7. A.E. Taggi, A.M. Hafez, H. Wack, B. Young, D. Ferraris and T. Lectka, J. Am. Chem. Soc., 124, 6626 (2002).

8. J. Salimon, N. Salih, H. Ibraheem and E. Yousif, Asian J. Chem., 22, 5289 (2010).

9. E. Yousif, F. Muaiad and H. Adil, J. Al-Nahrain Univ. (Sci.), 14, 44 (2010).

10. E. Yousif, H. Adil and Y. Farina, J. Appl. Sci. Res., 6, 879 (2010).

11. E. Yousif and E. Rentschler, J. Al-Nahrain Univ. (Sci.), 13, 86 (2010).

12. A. Majeed, E. Yousif and Y. Farina, J. Al-Nahrain Univ. (Sci.), 13, 36 (2010).

13. H. Ibraheem, H. Adel, A. Ahmed, N. Salih, J. Salimon, A. Graisa, Y. Farina and E. Yousif, J. Al-Nahrain Univ. (Sci.), 13, 43 (2010).

14. E. Yousif, Y. Farina, K. Kasar, A. Graisa and K. Ayid, Am. J. Appl. Sci., 6, 582 (2009).

15. R. Sliverstein, G. Bassler and T. Morrill, Spectrometric Identification of Organic Compounds, John-Wiley, New York, edn. 7 (2005).

16. K. Nakamoto, Infrared of Inorganic and Coordination Compounds, John-Wiley, New York, edn. 6 (1997).

17. N.N. Green Wood and A. Earnshow, Chemistry of the elements, Elsevier Science Ltd., edn. 2 (2002).

18. B.N. Figgis, Ligand Field Theory and its Applications, John-Wiley, New York, edn. 1 (2000).

19. C.K. Jorgensen, Optical Spectra and Chemical Bonding in Inorganic Compounds, Springer (2004).

20. J. Salimon, N. Salih, H. Hussien and E. Yousif, Eur. J. Sci. Res., 31, 256 (2009).

21. Y.-F. Win, E. Yousif, A. Majeed and S.-T. Ha, Asian J. Chem., 23, 5009 (2011).

22. D.C. Harris, Quantitative Chemical Analysis, W.H. Freeman and Company, New York, edn. 8 (2010).

23. E. Yousif, H. Adil, A. Majeed A. Graisa and Y. Farina, ARPN J. Eng. Appl. Sci., 4, 39 (2009).

24. S. Frankle, S. Reitman and A.C. Sonnenwir, Gradwol's Clinical Laboratory Method and Diagnosis, C.V. Mosby Co., Germany, edn. 7 (1970). 